\title{
"Saviour siblings"
}

M Spriggs, J Savulescu

In Victoria, Australia, some parents are now able to select embryos free from genetic disease which will provide stem cells to treat an existing sibling

A n Australian couple from Victoria have been given permission to use in vitro fertilisation (IVF) technology to screen an embryo in order to "create a 'perfect match' sibling" for their seriously ill child. In vitro fertilisation is regulated in Victoria by the Infertility Treatment Authority (ITA) which restricts access to people who are medically infertile or who have a family history of genetic disease. The approval given to the Victorian couple is for a new application of IVF consisting of preimplantation genetic diagnosis (PGD) together with tissue typing.

The couple's three year old daughter Christina has Fanconi's anaemia, a rare genetic condition, that means she will die before she turns 15 unless she receives blood from the umbilical cord of a "perfect match" sibling. Some people are saying this use of IVF amounts to the creation of a genetically engineered "designer" baby. ${ }^{1-6}$

Preimplantation genetic diagnosis is an IVF technique used to screen out genetic disease but Christina's parents want the embryos tested for compatible tissue type as well. Tissue typing or HLA (Human Leukocyte Antigen) typing goes beyond the approved guidelines in Victoria and Christina's parents had to ask Victoria's Infertility Treatment Authority for permission to take the extra step. ${ }^{12}$

Although permission has been given for the procedure to go ahead, the ITA's interim policy imposes some conditions. It can be used only to save a terminally ill sibling: "You couldn't use it to save a wife or husband with leukaemia, for example", said the ITA chief executive. And the resulting child should only provide cord blood or bone marrow. The harvesting of organs such as kidneys is not acceptable. Each application to use the procedure must also be reviewed by the authority.

In England, the Human Fertilisation and Embryology Authority (HFEA) regulates infertility treatment and follows similar principles to the ITA. The HFEA has given "in principle" approval to PGD and tissue typing but applications must be considered on a "'case-bycase basis" by an HFEA licence committee before the technique can be used. And licences "will be subject to strict conditions". According to Ruth Deech, chairman of the HFEA: "Where PGD is already being undertaken we can see

\section{Current controversy}

The Victorian Infertility Treatment Authority has given permission to allow tissue typing in combination with preimplantation genetic diagnosis. This is a new application of IVF. Not only will it allow parents to select an embryo free from serious genetic disease it will allow them to simultaneously select for a match so that the umbilical cord blood of the resulting baby can provide stem cells to treat an existing sibling who has a disease.

how the use of tissue typing to save the life of a sibling could be justified. We would see this happening only in very rare circumstances and under strict controls". ${ }^{7}$ In the US, tissue typing together with PGD has been carried out successfully. ${ }^{58}$

The Victorian ITA's decision to allow the procedure has sparked a range of reactions. According to one commentator, giving prospective parents "the right to shun a disabled child" verges on "reproductive discrimination" and the resulting child "would have a 'closed' future". Another sees it as "a form of selective breeding" and asks: "What happens to the embryos not lucky enough to be chosen as a tissue match?" ${ }^{\prime \prime}$ In contrast to these views, the decision to allow the procedure has also been described as "a triumph for common sense" ${ }^{\prime 10}$

At present, IVF and tissue typing is only allowed for couples who have a history of genetic disease or infertility, that is, only for those who would otherwise be eligible for IVF. Some have argued, however, that it should be extended to all couples who have a child who would benefit from the creation of a matched sibling, even if they are fertile and do not have a history of genetic disease. ${ }^{10}$

The HFEA appears to have adopted this more controversial position:

While in the majority of cases there will be indications for PGD to select an embryo free from a heritable genetic condition, there are some cases in which an affected sibling requires tissue from a putative child who would not themselves be at risk, as with certain leukaemias. Considering this the Committee recommends that the technique should also be available where there is an existing sibling with a life-threatening but non-inherited condition. ${ }^{11}$
This has been said to be the first step towards designer babies. Christina's parents say that the child they hope to conceive "is not a means to an end". They feel they are being unfairly scrutinised over their motivation for having another child: "nowhere else are parents' motivations put under a microscope prior to conception-for example, a child conceived to inherit the family business or continue the family name". "We are not seeking to custom-design a baby, we just want permission to pick the one embryo that does not have the disease and is a compatible tissue match", they say. ${ }^{1}$

J Med Ethics 2002;28:289

\section{Authors' affiliations}

M Spriggs, J Savulescu, Ethics Unit, Murdoch Childrens Research Institute, Royal Childrens Hospital, Flemington Road, Parkville, Victoria, 3052, Australia;

spriggsm@murdoch.rch.unimelb.edu.au

\section{REFERENCES}

1 Riley R. Give us the chance to save our angel. Sunday Herald Sun 2002 Jan 13: news section: 3.

2 Riley R. Design baby. Sunday Herald Sun 2001 Dec 23: news section: 1 \& 4

3 Hudson F. Design baby go-ahead. Herald Sun 2002 Apr 16: news section: 1 \& 4

4 Dubecki L. Special babies to save siblings. The Age 2002 Apr 16: news section: 1.

5 Hudson F. Parents' plea on baby plan. Herald Sun 2002 Apr 17: news section: 7.

6 Hill-Douglas 0 . God's 'design' offers a young girl a chance. The Age 2002 Apr 17: news section: 1-2.

7 HFEA press release. HFEA to allow tissue typing in conjunction with preimplantation genetic diagnosis, 13 December 2001. http://www.hfea.gov.uk/frame.htm

8 Riley R. Design baby ruling plea. Sunday Herald Sun 2002 Apr 14: news section: 19.

9 Keenan A, Stock S. 'Closed future' for saviour siblings. The Australian 2002 Apr 17: news section: 3

10 Boyle RJ, Savulescu J. Ethics of using preimplantation genetic diagnosis to select a stem cell donor for an existing person. British Medical Journal 2001;323:1240-3.

11 Ethics Committee of the Human Fertilisation and Embryology Authority. Ethical issues in the creation and selection of preimplantation embryos to produce tissue donors. London: 2001 Nov 22: section 3.14. 